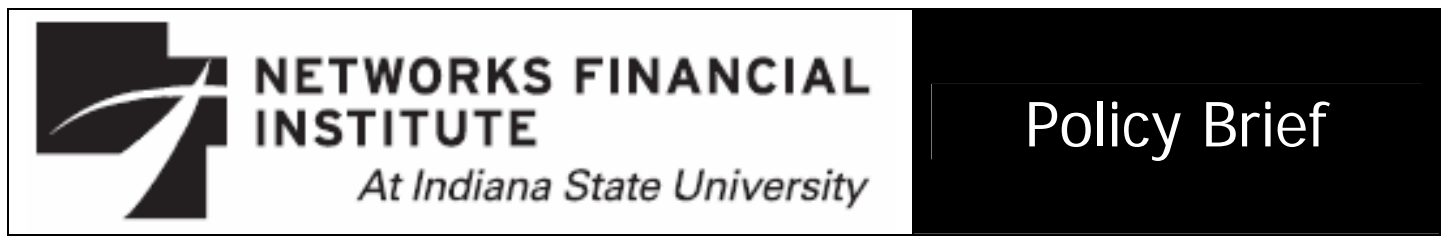

2007-PB-10

September 2007

\title{
Assessing Banks' Cost of Complying with Basel I I
}

\section{David VanHoose}

Abstract: This policy brief assesses the implications of Basel II for bank regulatory compliance costs. In spite of widespread complaints by bankers about the costs of complying with Basel II rules, the academic literature has given surprisingly little attention to quantifying these costs. The brief discusses estimates of Basel II compliance costs based on commonly utilized rules of thumb and on survey data collected by the Office of the Comptroller of the Currency (OCC). In addition, it utilizes OCC bank-level compliance-cost estimates to speculate about the potential for economies of scale in Basel II compliance. There is unavoidable imprecision associated with compliance-cost estimates. Nevertheless, costs of implementing Basel II ultimately should matter for the U.S. banking industry, both in terms of how the overall magnitudes of compliance costs may influence banks' strategic-path choices as well as their on-going operating decisions.

About the Author: David VanHoose is a Senior Fellow at Networks Financial Institute. VanHoose earned his Ph.D. at the University of North Carolina at Chapel Hill and is currently the Herman W. Lay Professor of Private Enterprise at the Hankamer School of Business at Baylor University. He has published articles in such professional journals as the Quarterly Journal of Economics, the International Economic Review, the Southern Economic Journal, the Journal of Money, Credit, and Banking, Economic Inquiry, and the Scandinavian Journal of Economics.

Keywords: Basel II, bank regulatory compliance costs.

J EL Codes: G28, E51.

The views expressed are those of the individual author and do not necessarily reflect official positions of Networks Financial Institute. Please address questions regarding content to David VanHoose at David_VanHoose@baylor.edu. Any errors or omissions are the responsibility of the author. Th author is grateful for helpful discussions with J ohn Pattison about Basel II compliance-cost issues.

NFI working papers and other publications are available on NFI's website (www.networksfinancialinstitute.org). Click "Research" and then "Publications/Papers." 


\section{Assessing Banks' Cost of Complying with Basel II David VanHoose}

\section{Introduction}

The Basel II framework for bank regulation, presently slated for a phased implementation by participating nations beginning in 2009, will entail a segmented system of risk-based capital requirements for banking institutions. In one category will be perhaps as many as a dozen banks with more than $\$ 250$ billion in assets or at least $\$ 10$ billion in on-balance-sheet foreign risk exposures. These specific institutions will be required to adopt a so-called advanced internal ratings-based approach, referred to henceforth as a "full Basel II" requirements system. In addition, other banks meeting minimal infrastructure requirements can voluntarily adopt the full Basel II framework. Depending on exactly how U.S. regulators ultimately decide to phase in Basel II rules, remaining institutions will either continue to be subject to essentially the rules previously in place under Basel I or opt to be regulated under a "Basel IA" framework utilizing an expanded set of risk weightings for required capital, particularly in relation to mortgage loans. Originally, small and medium-sized institutions were to have been regulated under the Basel IA, but regulators presently are discussing an alternative, as-yet-undefined "standardized approach," perhaps modeled on the European approach, to capital risk assessments.

Much of the research relating to Basel II has explored the nature of the suggested benefits of the new regulatory framework. Most discussion of the system directs attention to potential benefits of capital regulation - the so-called "first pillar" of the Basel II framework-in the form of risk 
reductions and enhanced bank safety and solvency [see VanHoose (2006, 2007a) for recent reviews]. In addition, some consideration has been given to the possibility of benefits arising via enhanced regulatory coordination and market discipline [see VanHoose (2007b)].

This policy brief focuses on assessing the implications of Basel II for bank regulatory compliance costs. In spite of widespread complaints by bankers about the costs of complying with Basel II rules, the academic literature has given surprisingly little attention to quantifying these costs. Section 2 discusses estimates of Basel II compliance costs based on commonly utilized rules of thumb, and section 3 examines estimates implied by survey data collected by the Office of the Comptroller of the Currency (OCC). Section 4 utilizes the OCC bank-level compliance-cost estimates to speculate about the potential for economies of scale in Basel II compliance. Section 5 discusses the unavoidable imprecision associated compliance-cost estimates. Section 6 evaluates how costs of implementing Basel II ultimately matter for the U.S. banking industry. Section 7 concludes.

\section{Rule-of-Thumb Estimates of Overall Basel II Compliance Costs}

How many dollars' worth of resources will U.S. banks expend in order to comply with Basel II? In spite of the fact that virtually all regulators and bankers agree that expenditures are likely to be relatively high, there has been very little investigation of this question.

Most references to the costs of complying with Basel II refer to ruleof-thumb estimates. For instance, it is common to see references in the financial media to speculation that 10 percent or more of banks' information-technology spending has been allocated to Basel II compliance 
since the early 2000s. Another rule of thumb [see, for instance, Hitt et al. (1998)] is that as much as 15 percent of banks' non-interest expenditures are information-technology-related.

Such rule-of-thumb estimates typically do not separate out quasifixed setup costs from ongoing compliance costs. Let's conservatively suppose, however, that these aspercentages apply to the present value of all combined expenses related to Basel II compliance, and let's apply such rules of thumb to aggregate U.S. banking data. In 2006, the FDIC reports (Quarterly Banking Profile, 2006) non-interest expenses for the 7,402 commercial banks then operating of about $\$ 290.3$ billion. If we more conservatively assume that 10 percent of these were costs related to information technology, and if 10 percent of these expenditures were related to Basel II compliance, then the implied total cost estimate for Basel II compliance is roughly $\$ 2.9$ billion. This averages out to total compliance costs of just over $\$ 390,000$ per U.S. commercial bank.

One would be hard pressed to find the underlying assumptions behind the rule-of-thumb ratios commonly espoused in discussions of Basel II compliance costs. Nevertheless, the above point estimate follows directly from applying conservative versions of these rules of thumb. The estimate is very imprecise, however. Suppose, for instance, that banks' informationtechnology-related expenses really are as much as 15 percent of their noninterest expenditures. Then applying the 10 percent rule of thumb for Basel II compliance costs as a share of information technology spending to the 2006 data boosts the estimated overall Basel II compliance cost-again, conservatively assumed to equal the discounted present value of the entire stream of Basel II-related costs - to nearly $\$ 4.4$ billion (or almost $\$ 590,000$ per commercial bank). Naturally, reducing either or both of the rule-of- 
thumb percentages cuts into the resulting point estimate. For example, if the share of banks' non-interest expenditures devoted to information technology is actually only 5 percent and the share of the latter expenses related to Basel II compliance is only 5 percent, then the point estimate for Basel II costs drops to only about $\$ 725$ million (about $\$ 98,000$ per bank).

\section{Estimates of Overall Basel II Compliance Costs Based on Survey Data}

Instead of relying on rules of thumb, the Office of the Comptroller of the Currency $(2006 a, b)$ surveyed banks about their own estimates of costs in implementing the new Basel II rules. In principle, the OCC's approach offers hope for somewhat greater precision.

The OCC concludes that for the 65 nationally chartered banks it judges to be most likely to utilize either Basel II or Basel IA requirements, the combined compliance costs (discounted present value for 2006) amount to about $\$ 473$ million. Across these 65 commercial banks, this estimate implies an average total compliance cost of just under $\$ 7.3$ million per institution. The OCC further estimates that if all nationally chartered banks were to adopt Basel II or Basel IA regulatory requirements, the combined compliance costs (again as a discounted present value of all costs as of 2006) would be nearly $\$ 1.1$ billion, or almost $\$ 680,000$ per institution.

Of course, these OCC estimates apply only to nationally chartered banks, or just over 20 percent of the U.S. banking system (albeit a portion containing many of the largest U.S. banks). Thus, the low-end total compliance-cost estimate of $\$ 725$ million yielded by a rule-of-thumb-style approach is almost certainly too low. Indeed, these OCC cost estimates for nationally chartered banks make the overall compliance-cost range of $\$ 2.9$ billion to $\$ 4.4$ billion begin to look more reasonable. 
Based on banks' survey responses, the OCC found that among commercial banks required only to meet Basel IA standards, an average institution with assets of less than $\$ 100$ million faced a total (discounted present value in 2006) cost of $\$ 100,000$; a bank with assets between $\$ 100$ million and $\$ 1$ billion confronted a total cost of $\$ 500,000$; a bank with assets between $\$ 1$ billion and $\$ 10$ billion faced a total cost of $\$ 1$ million; and a bank with assets exceeding $\$ 10$ billion confronted a total cost of $\$ 3$ million. Finally, the OCC estimated that a typical bank utilizing the full Basel II regulatory framework faced a total compliance cost of about $\$ 21$ million.

Now consider the result of applying these OCC compliance-cost estimates to the entire U.S. banking system. In 2006, the FDIC (Quarterly Banking Profile) reports that there were 3,246 banks with assets less than $\$ 100$ million, 3,662 banks with assets between $\$ 100$ million and $\$ 1$ billion, 406 banks with assets between $\$ 1$ billion and $\$ 10$ billion, and 88 banks with assets exceeding $\$ 10$ billion. Of the last set, let's suppose for the sake of conservatism that the OCC's 19 banks are the only banks that initiate full implementation of Basel II regulatory standards and that the remaining 69 very large banks continue to utilize Basel IA standards. Applying the OCC's per-bank estimates within each size class and totaling yields a total compliance cost estimate of almost $\$ 2.8$ billion, or close to the $\$ 2.9$ billion rule-of-thumb estimate obtained above.

\section{4. "Economies-of-Basel II"-Scale Advantages in Basel II Compliance?}

The OCC's (2006a, b) estimates of total compliance costs by bank size can be utilized to develop rough estimates of average costs per dollar of assets of implementing either the standardized Basel 1A or full Basel II systems. Suppose that we use the midpoint of each classification discussed 
above for the Basel IA banks (for instance, $\$ 50$ million for banks with assets less than $\$ 100$ million, $\$ 550$ million for banks with assets between $\$ 100$ million and $\$ 1$ billion, and so on) as the denominator of averagecompliance-cost ratios for banks with assets falling within the ranges with endpoints. According to American Banker (2007), on December 31, 2006 the average assets of a bank among the top 25 commercial banks in the United States (among which presumably is the set required to use or opting to utilize the full Basel II framework, denoted "Full Basel II" in the figure) was about $\$ 339$ billion. Among all others exceeding $\$ 10$ billion in assets, the average bank had about $\$ 21$ billion in assets. To obtain rough estimates of average compliance costs in relation to assets, these figures were used as denominators for the largest two groups of banks.

The resulting estimates of average compliance costs in relation to bank assets, displayed in Figure 1, are suggestive of a relationship that yields two potential implications. First, there appears to be a likelihood of significant diseconomies of scale in terms of Basel II compliance costs for banks with less than $\$ 1$ billion in assets. On a proportionate basis, the OCC's estimates indicate that implementation costs may well be significantly higher for smaller banks than for larger banks.

Second, among banks with more than $\$ 1$ billion in assets, there may be compliance-cost diseconomies of scale for Basel IA banks that increase their scale from the $\$ 1$ billion- $\$ 10$ billion size category to the greater than $\$ 10$ billion size classification. Indeed, the OCC's estimates indicate that at some point beyond an asset size of $\$ 10$ billion, a bank experiences lower average compliance costs by opting for advanced internal ratings-based regulation under the full Basel II framework 


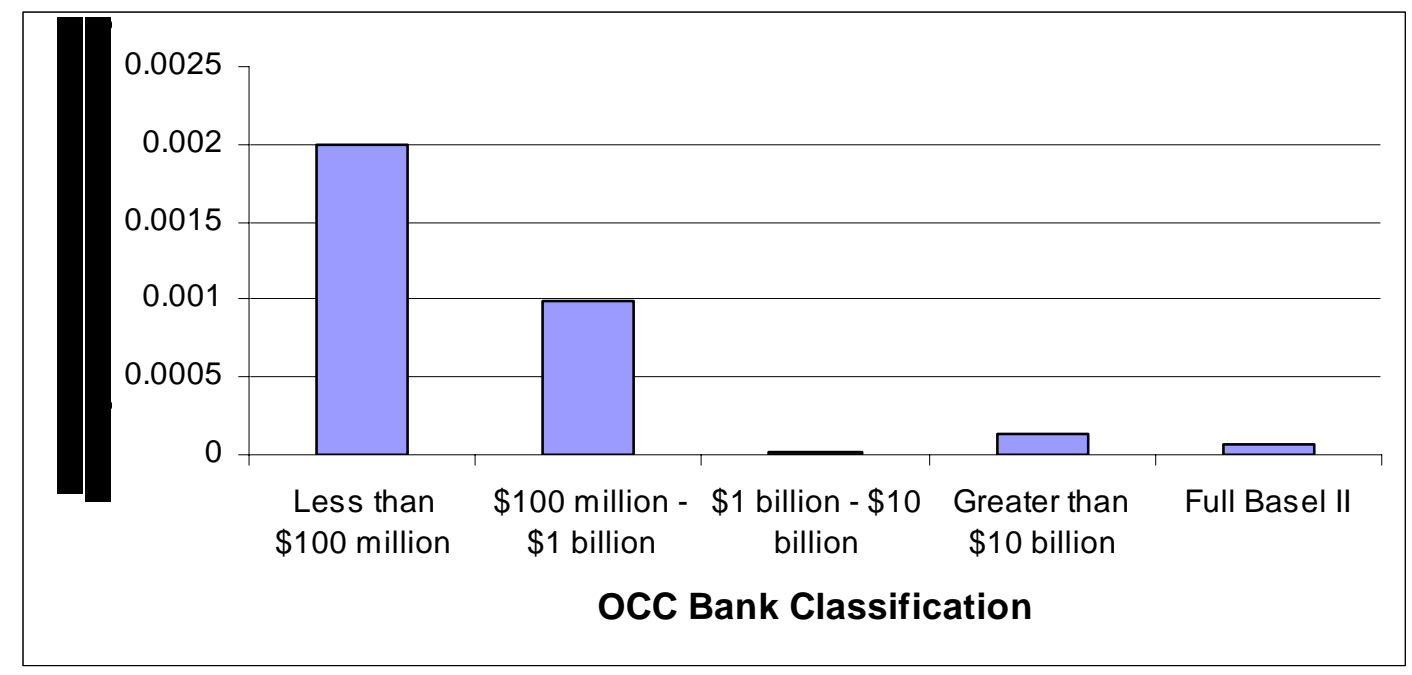

Figure 1

It should be emphasized that Figure 1 is based on back-of-theenvelope calculations utilizing compliance-cost estimates which, as discussed above, are subject to considerable imprecision. Nevertheless, Figure 1 hints at the potential for significant average compliance-cost differentials that might well emerge if a more thorough-going statistical study could be conducted utilizing more precise data on compliance costs across the full range of the U.S. bank-asset-size distribution.

\section{Difficulties in Assessing Basel II Compliance-Cost Estimates}

In assessing the estimates of compliance costs discussed above, it is important to recognize that in fact many bankers themselves do not carefully track all the costs that their institutions incur in complying with Basel II regulatory standards. A number of banks failed to carefully cost their Basel II expenses at the outset and hence cannot report hard and fast figures about their aggregate compliance costs. Because the most significant 
compliance costs have been related to information technology installation and development, a number of banks include only information-technologyrelated expenses when reporting their Basel II compliance costs. Thus, an unknown number of banks probably fail to report business-line costs related to Basel compliance and hence underestimate true compliance costs, even though human and other resource expenses devoted to Basel II can be relatively large.

Separating out Basel II compliance costs from other expenses surely can be a difficult proposition for most banks. Implementation of Basel II requires reconciling data generated by computer systems to all of a bank's general-ledger accounts. Furthermore, implementing Basel II requires significant data warehousing in order to compile histories of defaults, losses, and all other information relevant to risk rating systems, so that ratings can be retrospectively replicated. Naturally, risk managers would already be involved in some of these activities as a matter of course. Furthermore, prior to initiation of Basel II compliance efforts, every bank was at a different stage in its own adoption of accounting technologies and riskrating systems. In addition, banks may not always report all compliance costs related to subsidiaries, which may lead to some understatements. Thus, the portion of costs incurred in gearing up accounting and risk-rating systems that is driven by Basel II compliance naturally varies across banks, and within each bank this fraction of costs related to compliance likely varies over time as well.

Is it possible to generalize about costs specific to Basel II versus other non-interest expenses? On one hand, the OCC (2006b) notes that the 19 nationally chartered banks that are engaged in full Basel II implementation reported a per-bank average of total information technology expenses of $\$ 42$ 
million that could be related to Basel II implementation. But these banks guessed that roughly half of those expenditures involved adoption of information technologies that would have been put into place in any event, hence the OCC's \$21 million estimate of per-bank compliance costs. Undoubtedly, this "guesstimate" lies behind commonly encountered estimates that as much as 50 percent of banks' expenses on information technologies may be Basel II-related. On the other hand, this "guesstimate" only applies to banks implementing the full Basel II system. The OCC's compliance-cost estimates for smaller institutions suggest that banks adopting Basel IA surely incur compliance costs that are much less significant shares of their budgets for information technologies and other business lines.

It must be concluded that present estimates of overall Basel II compliance costs that commercial banks confront are unavoidably imprecise and potentially subject to considerable inaccuracy. An estimate of $\$ 2.8$ billion (discounted present value in 2006) for the entire U.S. banking system is probably every bit as reasonable as an estimate of $\$ 4.4$ billion or even higher. It is also possible that the total costs are less than $\$ 2.8$ billion, although the OCC estimates for nationally chartered banks alone suggest it is unlikely that overall compliance costs for U.S. banks are significantly lower than this amount.

Indeed, it may well be that actual compliance costs for the U.S. banking system will turn out to be closer to or even to exceed the higher-end rule-of-thumb estimate of $\$ 4.4$ billion. Recent informal statements by some bankers indicate that full Basel II compliance costs have turned out to be at least 50 percent higher than originally forecast and reported in the media. In addition, some surveys [see, for instance, Accenture (2005) and Risk 
Transfer Magazine (2005)] suggest that Basel II compliance cost projections for a number of internationally active European banks increased as these banks, which advanced more rapidly toward Basel II compliance than their U.S. counterparts, encountered previously unanticipated implementation costs. Sloan (2007), for instance, reports that internationally active banks with more than about $\$ 135$ billion in assets now anticipate spending an average of about $\$ 67$ million on Basel II compliance and that 20 percent of those banks now estimate compliance costs nearly double that amount. Furthermore, a recent survey by Ernst and Young (2006) suggests a global average full Basel II compliance cost of $\$ 70$ billion but also indicates that the top five Canadian banks' implementation costs exceed this amount.

Note that if these latter figures are correct, then the OCC estimate of a full Basel II compliance cost of $\$ 21$ million per institution is at least three times too low, implying less of a scale advantage from full Basel II implementation than indicated in Figure 1. Indeed, assuming that the OCC's Basel IA compliance-cost estimates are not also understated, a full Basel II implementation cost of $\$ 67$ million would boost the average compliance cost for a large bank required to utilize the full Basel II approach to a level about 40 percent higher than the average cost experienced by other large banks opting to the standardized Basel 1A regulatory methodology. In this case, the back-of-the-envelope calculations involved in producing the last bar displayed in Figure 1 would no longer hold true. The smallest of the very large banks required to comply with the full Basel II methodology would encounter a proportionate compliance-cost disadvantage relative to somewhat smaller institutions with greater than $\$ 10$ billion in assets that are able to utilize the standardized Basel 1A methodology. Furthermore, the institutions within the latter group obviously would not have a compliance- 
cost incentive to opt for full Basel II treatment after all.

\section{To What Extent Do Basel II Compliance Costs "Matter"?}

What are the implications of Basel II compliance costs for the U.S. banking system? The first part of the answer to this question relies on total discounted-present-value estimates of Basel II implementation costs. The second part of the answer depends on an assessment of the on-going variable costs associated with complying with the new regulatory framework.

\subsection{Total Implementation Costs}

To begin with, what does a discounted-present-value estimate of total Basel II implementation costs for the U.S. banking system of, say, $\$ 2.8$ billion or $\$ 4.4$, billion really mean? Based on data for the entire U.S. banking system in 2006, total compliance-cost estimates within the range of these amounts imply an average Basel II implementation expense ranging from just under 1 cent to perhaps about 1.5 cents per dollar of non-interest expenses. In relation to the aggregate 2006 net income of the U.S. banking system of just over $\$ 128.6$ billion, these total compliance cost estimates would imply the equivalent of a one-time 2 to 3.5 percent average charge against net income-a relatively significant "regulatory tax" on bank owners. Of course, if the recent reports of higher-than-anticipated compliance costs have any validity, the aggregate tax on bank profitability may well be higher.

Differences in total costs of implementing Basel II regulations across individual institutions stand to influence the distributional effects they will have on the banking system. Such cost differences obviously matter for 
large institutions that must choose between the standardized Basel 1A methodology versus the full Basel II internal-ratings-based approach. As discussed above, however, there are uncertainties regarding the eventual scope of the costs of implementing the full Basel II system. Hence, it is presently unclear whether a situation along the lines of the right-hand side of Figure 1 exists, or, alternatively, whether full Basel II implementation costs in fact are turning out to be much higher, so that the opposite may be true. One thing that is certain is that, in light of this uncertainty, some large banks facing a choice regarding whether to opt for the standardized approach or the internal-ratings-based approach have a difficult decision to make.

As noted above, it also appears likely that average costs of small community banks are likely to be disproportionately increased during the transition to the standardized Basel 1A framework. In the near term, smaller banks contemplating choices with respect to mergers or acquisitions might find that lower compliance costs associated with increased scale could be a factor that pushes them to act.

From an economic standpoint, there may not be much more to be discerned from analysis of discounted-present-value estimates of all anticipated costs to be incurred by banks in implementing Basel II. Estimates of discounted present values of streams of costs are of assistance in strategic choices of strategic paths to pursue-such as whether to choose between Basel IA or Basel II procedures or to opt for a change in scale in an effort to contain average costs.

\subsection{Variable Costs and Ongoing Effects of Basel II}

Once a bank and its competitors have chosen a strategic path to 
pursue, the factors that drive their behavior and, hence, influence market outcomes are the determinants of flows of revenues, expenses, and profits. Thus, effects of Basel II on banks' variable costs are what impinge on banks' week-to-week and month-to-month balance-sheet decisions-their lending and other portfolio-allocation choices and their decisions regarding liability mix - as well as their off-balance-sheet activities-securitization, derivatives trading, and so on.

Unfortunately, very little appears to be known about the ongoing effects that compliance with the Basel II framework are likely to have on banks' variable costs. Indeed, only a single point estimate appears to be available. As part of the its evaluation of the compliance costs faced by a typical bank operating under the internal-ratings-based approach of the full Basel II system, the OCC provides an estimate of an annual expense of \$2.4 million.

It is perhaps unsurprising that estimates of the flows of variable costs associated with Basel II implementation are nearly nonexistent. After all, economists struggle to measure the relevant variable costs that banks already face under the existing regulatory framework. Evaluating the ongoing burden of Basel II compliance clearly will require collection of variable-cost data once operations under Basel II begin.

\section{Conclusion}

Although there have been considerable references in the academic literature and the financial media to the costs that banks face in implementing the new Basel II regulatory framework, surprisingly few estimates of these costs have been developed. This brief has reviewed outstanding rules of thumb and survey estimates. 
Based on estimates of the total discounted present value of all implementation costs, the total compliance cost faced by the banking industry may be equivalent to a charge against a single year's earnings of as much as 3.5 percent. There potentially is considerable variation in average Basel II implementation costs across banks, with small banks likely to face higher average costs of complying with the new system than large banks.

It is also possible that, if otherwise on the margin, the largest banks that are permitted to choose between standardized Basel II requirements versus full adoption of the internal-ratings-based approach could opt for the latter on the basis of lower average compliance costs. This is far from certain, however, given the tenuous nature of the implementation-cost estimates for large banks adopting the internal-ratings-based methodology.

An important point to keep in mind in assessing these conclusions is that the focus of this brief has been solely on explicit compliance costs faced by banks. Implementation of Basel II likely will entail on- and off-balancesheet adjustments entailing a number of potential benefits and costs for the banking system and for the economy as a whole. In the context of a generalequilibrium calibrated simulation, the most conservative of Van den Heuvel's (2005) estimates of the ongoing costs to society generated by reduced liquidity is 0.1 percent of total consumption, or, based on 2006 data and in 2006 dollars, an annual consumption reduction somewhat below $\$ 10$ billion. Thus, while Basel II compliance costs are not trivial, it is conceivable that they are significantly less than the broader costs associated with bank balance sheet adjustment. Furthermore, both compliance costs and costs related to broader on- and off-balance-sheet adjustments together will ultimately determine the full competitive ramifications of Basel II adoption for the banking system. 



\section{REFERENCES}

Accenture. 2005. Banks slow in making progress toward Basel compliance, Accenture survey shows, July 25

(http://accenture.tekgroup.com/article_print.cfm?article_id=4237)

American Banker. 2007. Ranking the banks: Bank and thrift holding companies with the most assets on December 31, 2006, May 3.

Ernst and Young. 2006. Basel II: The business impact of Basel II sinking in as Canadian banks struggle with implementation. April 12. (http://www.ey.com/global/content.nsf/Canada/Media_-_2006__Basel_II)

Hitt, Lorin, Frances Frei, and Patrick Harker. 1998. How financial firms decide on technology, Wharton Financial Institutions Center Working Paper No. 98-34-B, November.

Office of the Comptroller of the Currency. 2006b. Regulatory impact analysis for risk-based capital guidelines, capital adequacy guidelines, capital maintenance, and domestic capital modifications. Office of the Comptroller of the Currency. 2006a. Regulatory impact analysis for risk-based capital standards, revised capital adequacy guidelines.

Risk Transfer Magazine. 2005. Basel costs don't dazzle bankers. September 26. (http://www.risktransfermagazine.com/xq/asp/sid.0/articleid.AF7CFB 58-91C1-4FE4-9649-2F2298A9A292/qx/display.htm)

Sloan, Steven. 2007. Treasury presses for a Basel regulatory consensus. May 9.

Sloan, Steven. 2007. Basel II compliance costing millions. American Banker. April 20. 
Van den Heuvel, Skander. 2005. The welfare cost of bank capital requirements. Working Paper, Wharton School, University of Pennsylvania, December.

VanHoose, David. 2007b. "Market Discipline and Supervisory Discretion in Banking: Reinforcing or Conflicting Pillars of Basel II?" Networks Financial Institute Working Paper No. 2007-WP-06, February 2007. http://www.networksfinancialinstitute.org/Lists/Publication\%20Libra ry/Attachments/56/2007-WP-06_VanHoose.pdf

VanHoose, David. 2007a. Theories of bank behavior under capital regulation. Journal of Banking and Finance 31, Forthcoming.

VanHoose, David. 2006. Bank behavior under capital regulation: What does the academic literature tell us? Networks Financial Institute Working Paper 2006-WP-04.

http://www.networksfinancialinstitute.org/Lists/Publication\%20Libra ry/Attachments/71/2006-WP-04_VanHoose.pdf 